\title{
Key to Nine Common Smilax Species of Florida ${ }^{1}$
}

\author{
Lynn Proenza and Michael Andreu ${ }^{2}$
}

\section{Family}

Smilacaceae

\section{Genus}

Smilax (catbrier, greenbrier, sarsaparilla)

\section{Introduction}

Identifying species found in Smilax the genus can be difficult because species resemble one another closely. One must be careful to use detailed descriptions in order to correctly identify a specimen. Smilax species are important because they can provide shelter and food for wildlife and have provided humans with medicine, food, and dyes.

Twelve Smilax species are found in Florida. This document covers the nine more common species that one may encounter in the state. These include:

- S. auriculata; earleaf greenbrier

- S. bona-nox; saw greenbrier

- S. glauca; cat greenbrier, wild sarsaparilla

- S. laurifolia; laurel greenbrier, bamboo vine

- S. pumila; sarsaparilla vine

- S. rotundifolia; bullbrier, roundleaf greenbrier

-S. smallii; Jackson vine, lanceleaf greenbrier

- S. tamnoides; bristly greenbrier, hogbrier

- S. walteri; coral greenbrier
Due to the small range and rarity of $S$. havanensis (listed as threatened by the state of Florida), and the small range of $S$. ecirrhata and S. lasioneuron (found only in a few counties in the panhandle), we will not include these three species.

The descriptions below list the ranges and habitats in which each species occurs along with their physical characteristics. The descriptions include a summary of distinctive characteristics that may prove helpful in differentiating between species and identifying them correctly. Frequently, leaf shape or color will vary on an individual plant, so it is important to look at more than one leaf or common characteristic to ensure proper identification.

Florida contains many different plant communities (habitats) in which Smilax species occur. Descriptions of these natural plant communities are found in the Guide to the Natural Communities of Florida (2010 edition), created by the Florida Natural Areas Inventory (FNAI).

\section{Common Traits of the Smilax Genus}

(To assist with terminology, which may be difficult for some readers, we recommend the book, Plant Identification Terminology: An Illustrated Glossary, by J. G. Harris and M. W. Harris, which includes both a definition and a picture for all botanical terms mentioned below.)

With the exception of Smilax walteri, which is deciduous, Smilax species in Florida are evergreen to semi-evergreen.

1. This document is FOR307, one of a series of the School of Forest Resources and Conservation, Florida Cooperative Extension Service, Institute of Food and Agricultural Sciences, University of Florida. Original publication date January 2013. Visit the EDIS website at http://edis.ifas.ufl.edu.

2. Lynn Proenza, graduate student; and Michael Andreu, associate professor; School of Forest Resources and Conservation, Institute of Food and Agricultural Sciences, University Florida, Gainesville, FL 32611. 
Of the 12 species in Florida, only two are herbaceous annuals: S. ecirrhata and S. lasioneuron; all the others develop woody stems. The woody Smilax species are rhizomatous and spread via subterranean runners. They climb using tendrils, and all except for $S$. pumila are armed with sharp prickles on the stems. New stems grow very quickly and are somewhat succulent, becoming woody with age. Stems are typically green and squared or, in some cases, angled. The leaves are simple and alternate and typically have three or five major veins from the base to the apex. The small, clustered flowers are green, yellow, or brown. The fruit is a small berry 5-10 $\mathrm{mm}$ in diameter. Each fruit contains 1-4 reddish seeds.
Stems: Entangled commonly on low shrubs or on themselves. Glabrous. Lower stems of main shoots pinkish, purplish, or pinkish-orange. Prickles scattered, tips blackish.

Leaves: Evergreen. Twisted green petiole. Leaves leathery, shape and size variable, commonly oblong, sometimes ovate, lanceolate, suborbicular, or fiddle-shaped to $12 \mathrm{~cm}$ long, $5 \mathrm{~cm}$ broad. Upper leaf surface dull green, lower leaf surface with somewhat raised veins and lighter dull green. Tight revolute margins on mature leaves due to two veins (one cartilaginous) close together sometimes appearing as one. Apex commonly rounded, sometimes apiculate (having a mucronate tip), base obtuse, cuneate, or rounded.

\section{Dichotomous Key}

Each of the species within this key is linked to its physical description

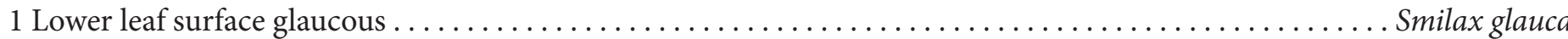

1 Lower leaf surface not glaucous

2 Leaf surfaces, petioles, and stems shaggy pubescent $\ldots \ldots \ldots \ldots \ldots \ldots \ldots \ldots \ldots \ldots \ldots \ldots \ldots \ldots \ldots \ldots$ Smilax pumila

2 Plant without shaggy pubescence

3 Prickles distinct, needle-like, shiny, black to brown in color, up to $1 \mathrm{~cm}$ long $\ldots \ldots \ldots \ldots$. Smilax tamnoides

3 Prickles without the above characteristics

4 Leaves predominantly round to cordate $\ldots \ldots \ldots \ldots \ldots \ldots \ldots \ldots \ldots \ldots \ldots \ldots \ldots \ldots \ldots$ Smilax rotundifolia 4 Leaves not predominantly round to cordate

5 Leaves predominantly lanceolate

6 Leaves droop downwards or are held horizontal, no submarginal vein ................Smilax smallii

6 Leaves held vertical (straight up) or horizontal, submarginal vein ............... Smilax laurifolia

5 Leaves more variable in shape

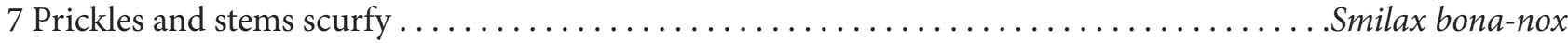

7 Prickles and stems not scurfy

8 Evergreen; petioles green, common in deep, sandy soils of upland ecosystems ........ Smilax auriculata 8 Deciduous; petioles reddish, common in bottomland ecosystems ................. Smilax walteri

\section{Species Descriptions}

\section{Smilax auriculata; catbrier, earleaf greenbrier}

Range and habitat: Throughout Florida, commonly near the coast. Deep, sandy soils. Common in disturbed sites, scrub, and coastal dunes; less common in marshes, savannahs, or flatwoods.
Flowers: Spring in north, year round in south. Dioecious. Green to yellowish-green, to $5 \mathrm{~mm}$ long.

Fruit: Red to black with age, glaucous, shiny to $13 \mathrm{~mm}$ in diameter.

Distinguishing characteristics: The lower stems of main shoots are pinkish, purplish, or pinkish-orange in color, unlike those of S. laurifolia. The petioles of S. auriculata are 
not red like those found on S. laurifolia. The tight revolute margins on mature leaves due to two sets of veins (one cartilaginous) close together sometimes appear as a groove. This is similar to S. laurifolia as its margins are slightly revolute. Site can help differentiate these two species because $S$. auriculata is common in dry ecosystems with deep sandy soils and S. laurifolia is common in bottomland ecosystems, sometimes with extended periods of inundation.

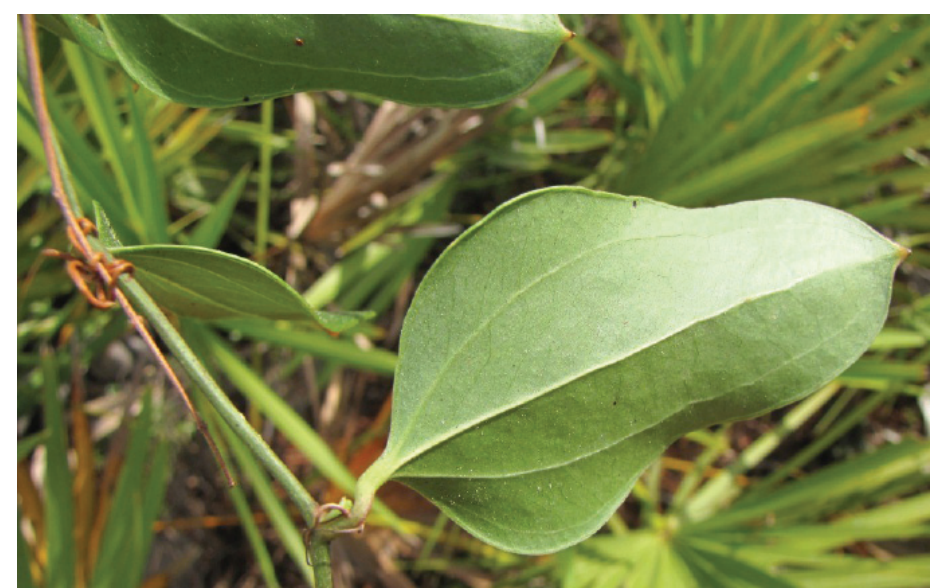

Figure 1. Smilax auriculata has revolute margins and the petioles are not red.

Credits: Lynn Proenza

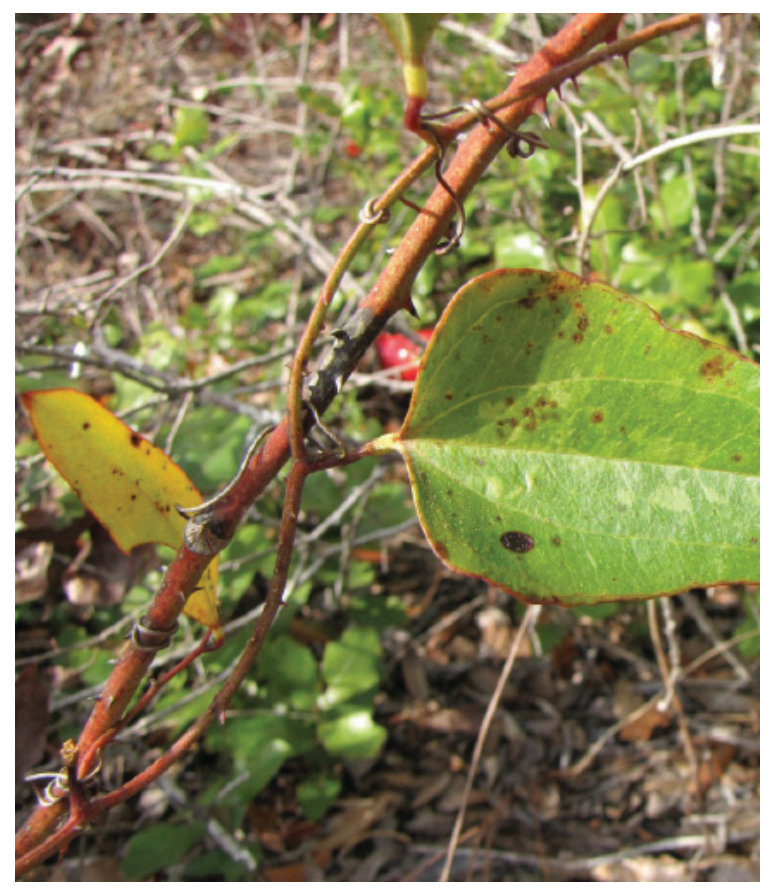

Figure 2. Mature stems of Smilax auriculata are pinkish, purplish, or pinkish-orange in color.

Credits: Lynn Proenza

\section{Smilax bona-nox; saw greenbrier}

Range and habitat: Throughout Florida in many different woodland ecosystems.
Stems: Can grow very high. Sharp prickles at internodes and nodes. Prickles and lower stems of main shoot with small scales (scurfy). Use a hand lens to see scales.

Leaves: Semi-evergreen. Leaves becoming thick and stiff with age. Three-lobed, ovate, or fiddle-shaped; 5-14 cm long and 1-12 $\mathrm{cm}$ broad. Upper leaf surface shiny and green, commonly variegated with gray or pale green blotches. Lower leaf surface paler green, veins sometimes with prickles. Margins with a band that is thick, with or without prickles (entire), apices obtuse, rounded and/or tapered at tip, bases cordate to truncate.

Flowers: Spring in north, year-round in south. White.

Fruit: Fall. Black. Shiny or dull, 6-8 $\mathrm{mm}$ in diameter. Contains a single, reddish-brown seed.

Distinguishing characteristics: The prickles and lower stems of the main shoot are scurfy. No other Smilax species on this fact sheet has that characteristic. The margin of the leaf is thick and prickles are sometimes present. S. tamnoides also bears prickles on the leaves; however, magnification with a hand lens is required to see them. S. rotundifolia margins can also have prickles, but the general leaf shape is round.

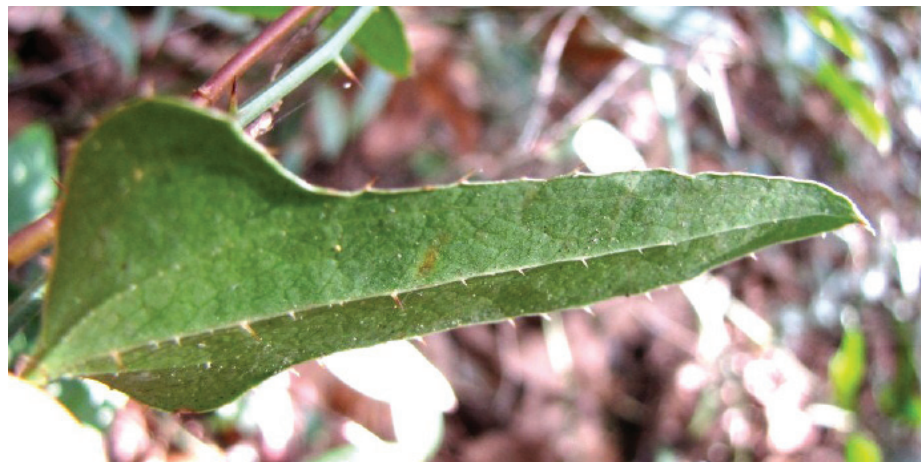

Figure 3. Prickles on the margin and along the midrib on the lower leaf surface are common on Smilax bona-nox. Credits: Lynn Proenza

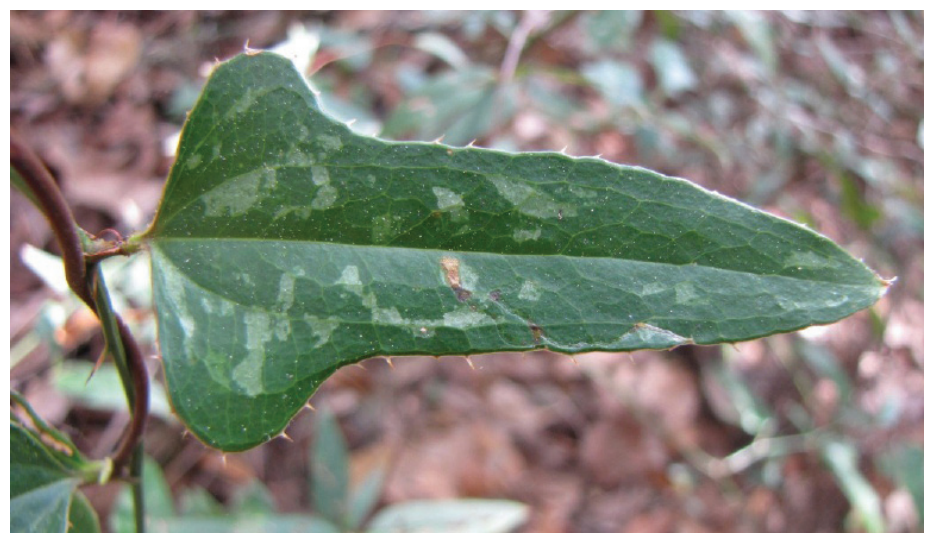

Figure 4. The upper leaf surface on Smilax bona-nox is commonly variegated with gray or pale green blotches.

Credits: Lynn Proenza 


\section{Smilax glauca; cat greenbrier, wild sarsaparilla}

Range and habitat: North to central Florida. Various woodland ecosystem types. Grows alongside S. bona-nox and S. tamnoides.

Stems: Glabrous stems and prickles.

Leaves: Semi-evergreen. Ovate, 4-10 cm long. Upper leaf surface green, lower leaf surface strongly glaucous. Margins entire, apex short acuminate, base ovate, truncate, or subcordate.

Flowers: Spring to fall. Yellowish-brown.

Fruit: Berry persistent, bluish-black and shiny, approximately $8 \mathrm{~mm}$ in diameter.

Distinguishing characteristics: The lower leaf surface is strongly glaucous. No other Smilax species on this fact sheet is this prominently glaucous.

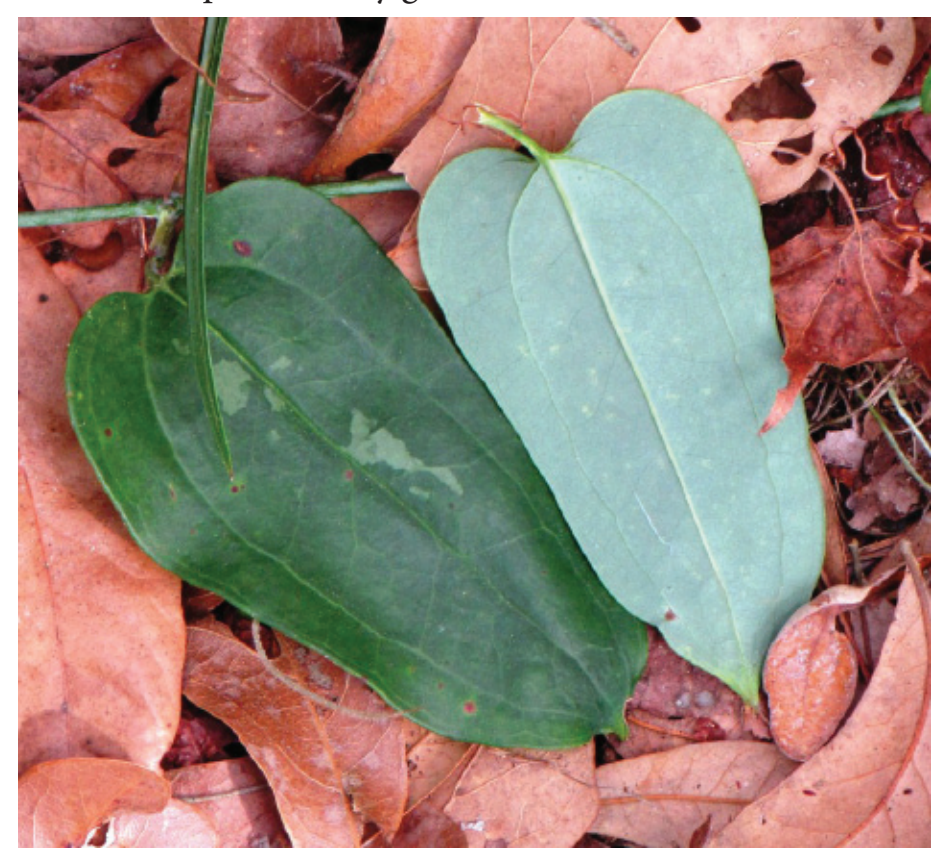

Figure 5. The glaucous coating on the lower surface of the leaf (right side of photo) on Smilax glauca is an excellent distinguishing characteristic for this species.

Credits: Lynn Proenza

\section{Smilax laurifolia; laurel greenbrier, bamboo vine}

Range and habitat: Throughout Florida. Various bottomland ecosystem types sometimes with extended periods of inundation.

Stems: High-climbing, mat forming. Numerous prickles on lower stem. Rhizomes thick and reddish.
Leaves: Evergreen. Leaves appear to be held vertically (straight up) due to twisted, reddish, petioles. Thick, leathery, oblong to lanceolate, 5-15 cm long. Upper leaf surface dark green, veins not apparent; lower leaf surface with a prominent midvein, lateral veins not as apparent, occasionally glaucous. Margins with submarginal vein running parallel to edge, slightly revolute, apex apiculate and rounded, base obtuse to rounded.

Flowers: Late spring to summer. Greenish-white to $5 \mathrm{~mm}$ long, aromatic.

Fruit: Berry glabrous, black, and shiny, 5-8 $\mathrm{mm}$ in diameter. Persistent.

Distinguishing characteristics: The lower leaf surface has a prominent midvein, whereas lateral veins are not as prominent, if at all. The leaves appear to be held vertically. The petioles are reddish in color, whereas $S$. auriculata petioles are green. Margins are slightly revolute, whereas the margins of S. auriculata are more strongly revolute. Site can also help differentiate these two species because $S$. auriculata is common in dry ecosystems with deep, sandy soils, and $S$. laurifolia is common in bottomland ecosystems, sometimes with extended periods of water inundation.

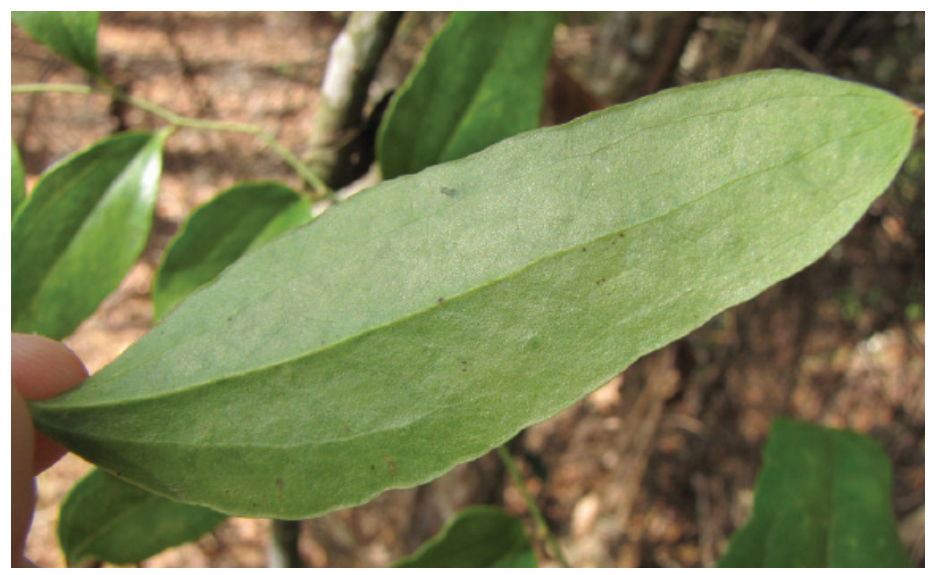

Figure 6. Smilax laurifolia's midvein is prominent when compared to the lateral veins.

Credits: Lynn Proenza

\section{Smilax pumila; sarsaparilla vine}

Range and habitat: North to central Florida. Bottomlands, mesic and xeric woodlands, maritime forests, scrub.

Stems: Typically found low climbing or along the ground. Tan, slender, and shaggy-pubescent, commonly less than 50 cm long. No prickles.

Leaves: Evergreen. Petiole shaggy pubescent. Ovate, oblong, to oval, to $4-12 \mathrm{~cm}$ long, 3-5 $\mathrm{cm}$ broad. Upper leaf surface 
dark green. Lower leaf surface with dense pubescence, grayish. Margins entire, apices apiculate, bases cordate.

Flowers: Spring to fall.

Fruit: Spring. Fruit persists. Bright red, containing a single seed. Apex tapers.

Distinguishing characteristics: The shaggy pubescence along stems, petioles, and the lower leaf surface sets this species apart from the others. The stems lack prickles and typically trail along the ground. The red berries have a tapered apex, whereas the berries on S. walteri are round.

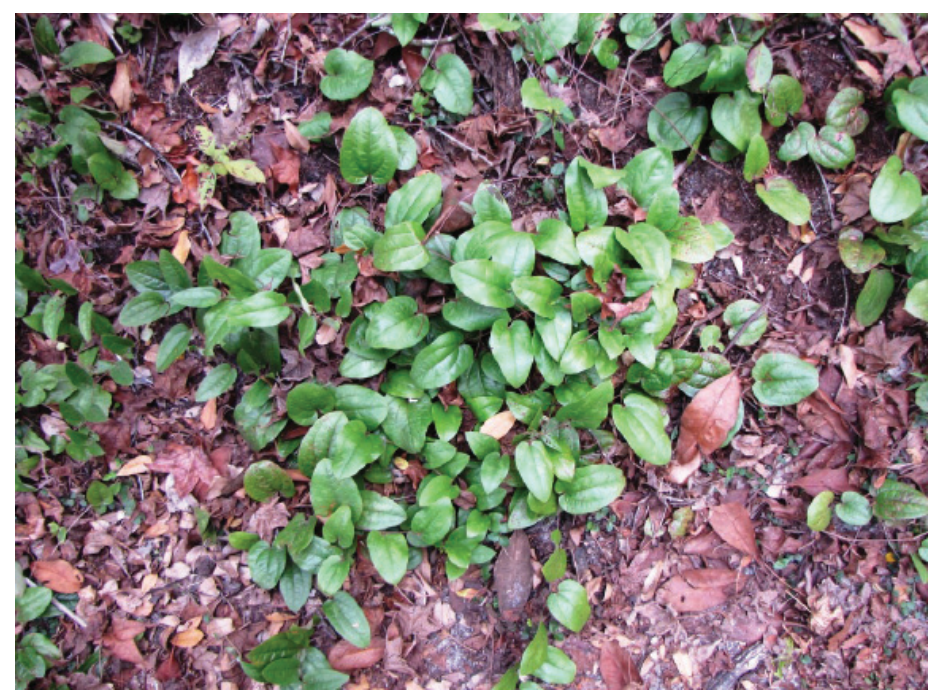

Figure 7. Smilax pumila is typically found trailing along the ground. Credits: Lynn Proenza

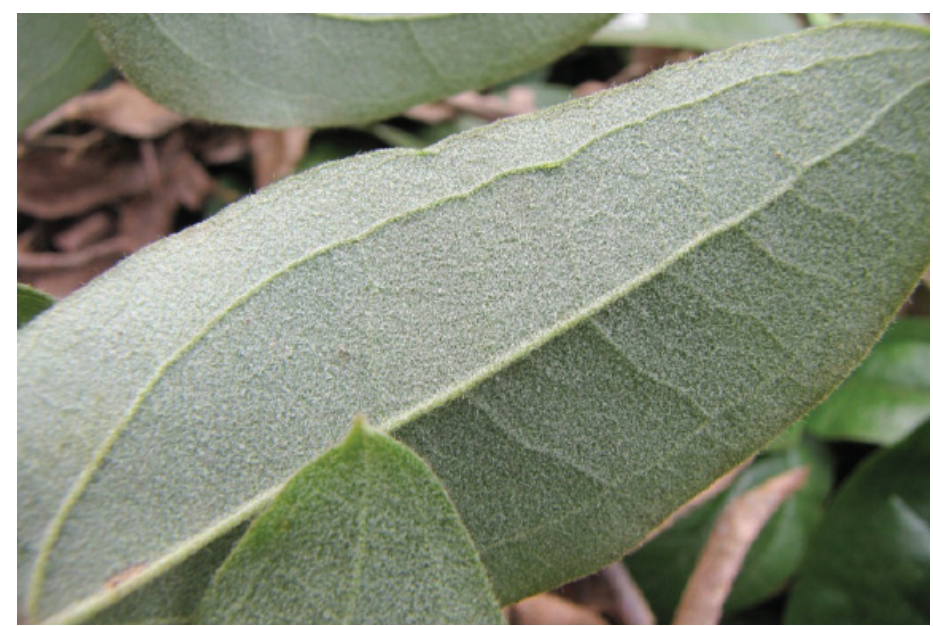

Figure 8. The gray, shaggy pubescence found covering the leaf surface, petiole, and stem is the best way to distinguish Smilax pumila from other Smilax species.

Credits: Lynn Proenza

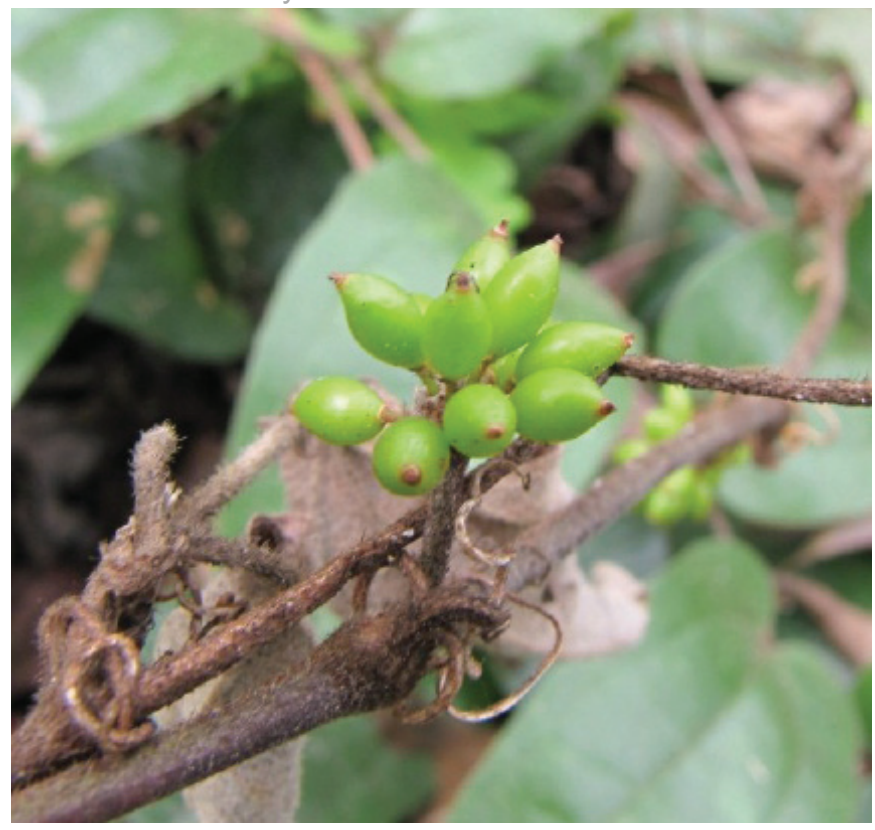

Figure 9. The fruit tapers toward the tip on Smilax pumila and is red when mature.

Credits: Lynn Proenza

\section{Smilax rotundifolia; bullbrier, roundleaf greenbrier}

Range and habitat: North Florida. Commonly found in mesic woodlands and on edges of wooded lakes and ponds.

Stems: High climbing. Glabrous. Prickles found on internodes only to $8 \mathrm{~mm}$ long, brown to reddish tip.

Leaves: Semi-evergreen. Petioles reddish, soft toothed. Petiole wings also sometimes toothed. Leaves varying in size and shape typically cordate, rounded, or ovate to $10 \mathrm{~cm}$

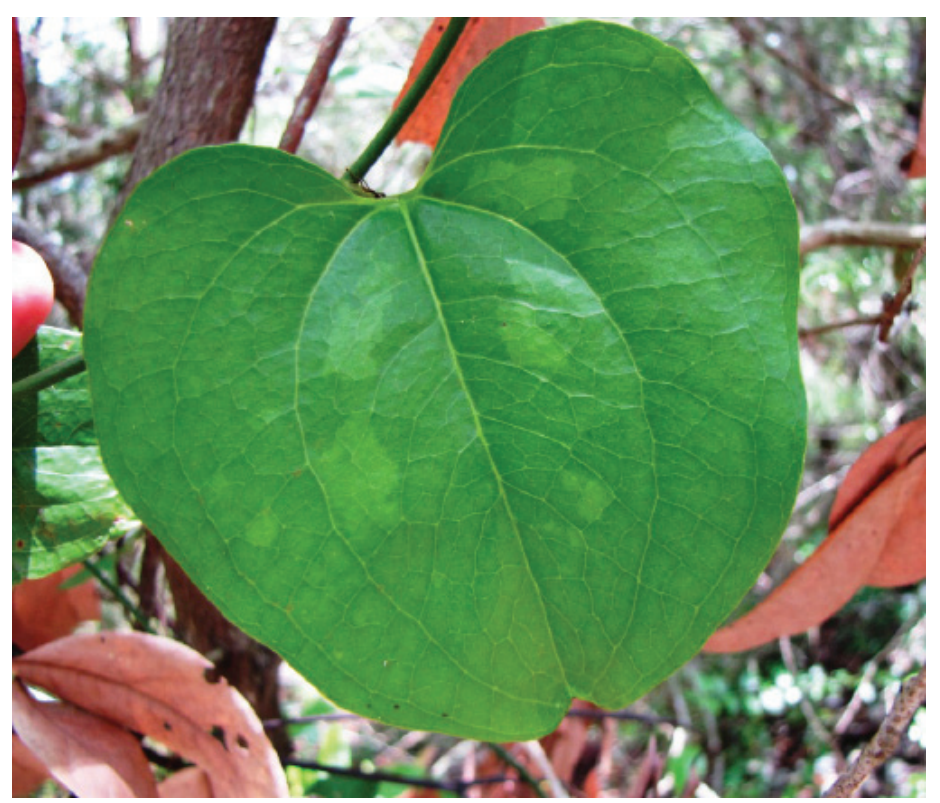

Figure 10. Smilax rotundifolia leaves typically have a cordate or rounded appearance.

Credits: Lynn Proenza 
long. Leaves on main shoots are typically larger than those on branches. Leader shoot leaves reniform, but commonly ovate to $10 \mathrm{~cm}$ long, $15 \mathrm{~cm}$ broad. Upper leaf surface shiny and green, lower leaf surface light green. Margins thin, commonly not revolute, and sometimes toothed. Apices short and pointed, bases cordate, truncate, or subcordate. Leaves on branches commonly ovate, rarely elliptic or lanceolate to $8 \mathrm{~cm}$ long.

Flowers: Green to bronze. Small, to $6 \mathrm{~mm}$ long.

Fruit: Fall. Berries bluish-black, glaucous, contain 1-3 seeds.

Distinguishing characteristics: Petiole wings are sometimes toothed, whereas $S$. walteri lacks teeth on the wings. The general leaf shapes of $S$. rotundifolia are cordate to round, whereas many other Smilax species have varying leaf shapes.

\section{Smilax smallii; Jackson vine, lanceleaf greenbrier}

Range and habitat: North to central Florida. Rich woodlands, hammocks, mixed forests, fence and hedge rows, and well-drained sites. Uncommon where floods take place.

Stems: High climbing, glabrous. Leader stems to $2 \mathrm{~cm}$ thick. New shoots glaucous. Many sharp prickles on main stem only.

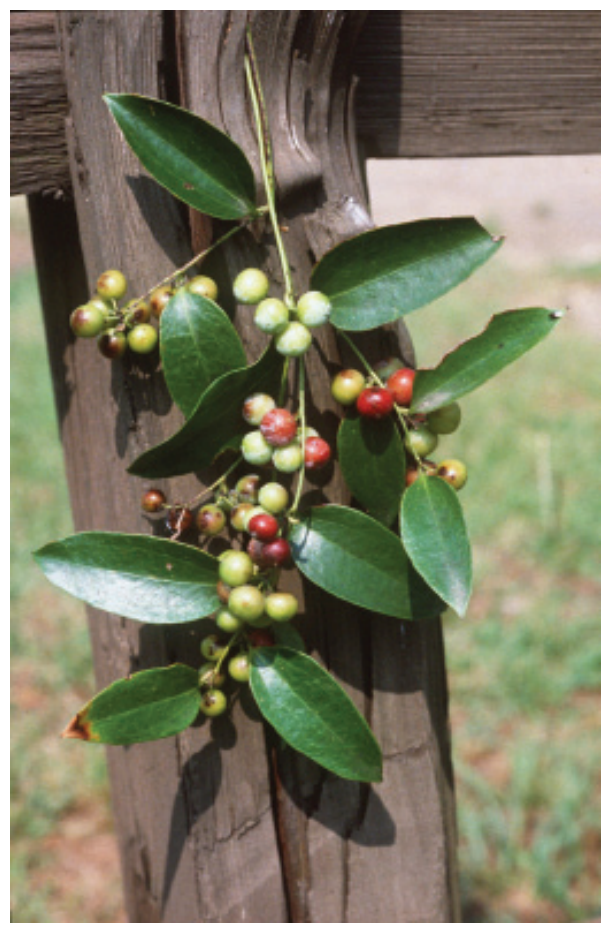

Figure 11. The leaves of Smilax smalli are lanceolate. Credits: Robert H. Mohlenbrock, USDA-NRCS PLANTS Database
Leaves: Evergreen. Leaves droop or are held horizontally, thin, lanceolate to occasionally ovate $4-10 \mathrm{~cm}$ long, $1-3$ $\mathrm{cm}$ broad. Upper leaf surface shiny and dark green; lower leaf surface pale, light green. Margins entire, apex acute to short-acuminate occasionally with an apiculate tip, base tapering.

Flowers: Summer. Yellowish-green.

Fruit: Late spring. Glaucous with reddish to brownish hues to black with age.

Distinguishing characteristics: The thin leaves are predominantly lanceolate and either droop or are held horizontally, unlike S. laurifolia or S. auriculata, which are predominantly held vertically. A submarginal vein does not exist on S. smallii as it does for S. laurifolia and S. auriculata.

\section{Smilax tamnoides; bristly greenbrier, hogbrier}

Range and habitat: North to south-central Florida. Commonly in upland and mesic woodlands but occurs in various ecosystem types. Typically found growing with $S$. glauca and S. bona-nox.

Stems: Rhizomatous. Shiny, dark-brown to black, needlelike, sharp prickles to $1 \mathrm{~cm}$ long on main stem, sometimes intermixed with shorter prickles.

Leaves: Semi-evergreen. Varying shapes from ovate, orbicular, subrotund, fiddle-shaped, to hastate to $15 \mathrm{~cm}$ long and broad. Upper and lower leaf surfaces green. Margins entire, sometimes minutely toothed (magnification with a hand lens required), apices long- to short-acuminate, short pointed, bases truncate to cordate.

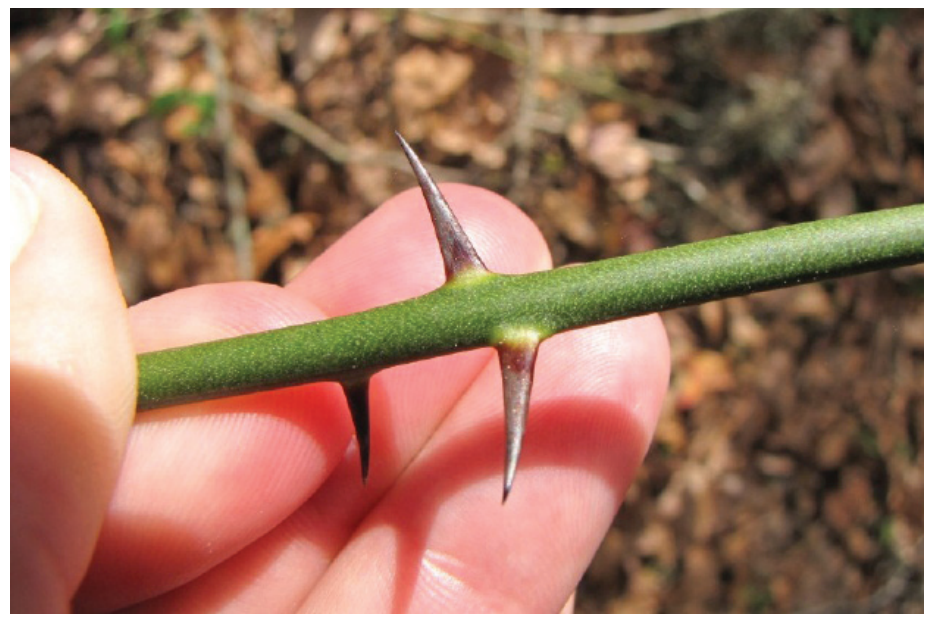

Figure 12. The prickles of Smilax tamnoides are needle-like, shiny, and dark-brown to black in color.

Credits: Lynn Proenza 
Flowers: Spring.

Fruit: Fall. Black berry containing 1-2 seeds.

Distinguishing characteristics: The shiny, dark-brown to black, needle-like prickles on the main stem are unlike those of any other Smilax species.

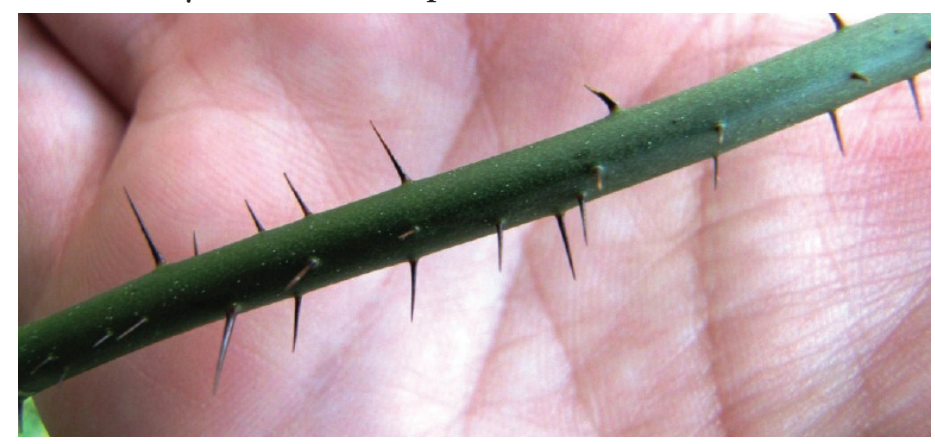

Figure 13. Prickles on younger growth of Smilax tamnoides are much more slender and needle-like, but are also very dark and shiny. Credits: Lynn Proenza

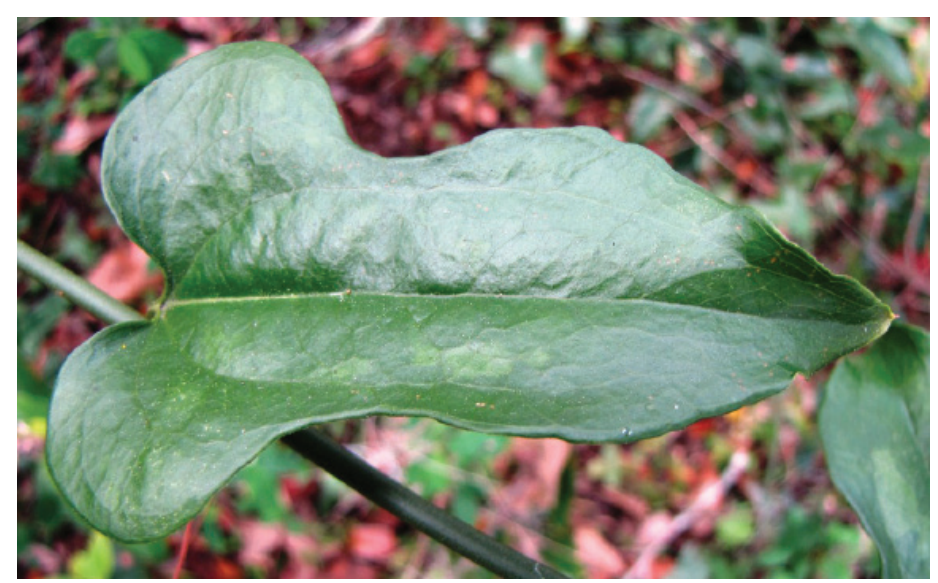

Figure 14. The leaves of Smilax tamnoides vary in shape but are mpredominantly fiddle-shaped.

Credits: Lynn Proenza

\section{Smilax walteri; coral greenbrier}

Range and habitat: North to central Florida. Found in habitats with standing water, bottomlands.

Stems: Climbs to $6 \mathrm{~m}$, mat-forming. Prickles uncommon, sharp, not found on nodes. Slender stems.

Leaves: Deciduous. Reddish petiole, wings lack teeth (compared to $S$. rotundifolia which have teeth on the wings). Varying shapes from ovate, orbicular, subrotund, and hastate but predominantly fiddle-shaped to $15 \mathrm{~cm}$ long.. Upper leaf surfaces green, lower surfaces commonly paler. Margins thin, commonly revolute, entire, apices obtuse to acute, tips short pointed, bases rounded to truncate.

Flowers: Spring. Dioecious. Yellowish-brown to $7 \mathrm{~mm}$ long.

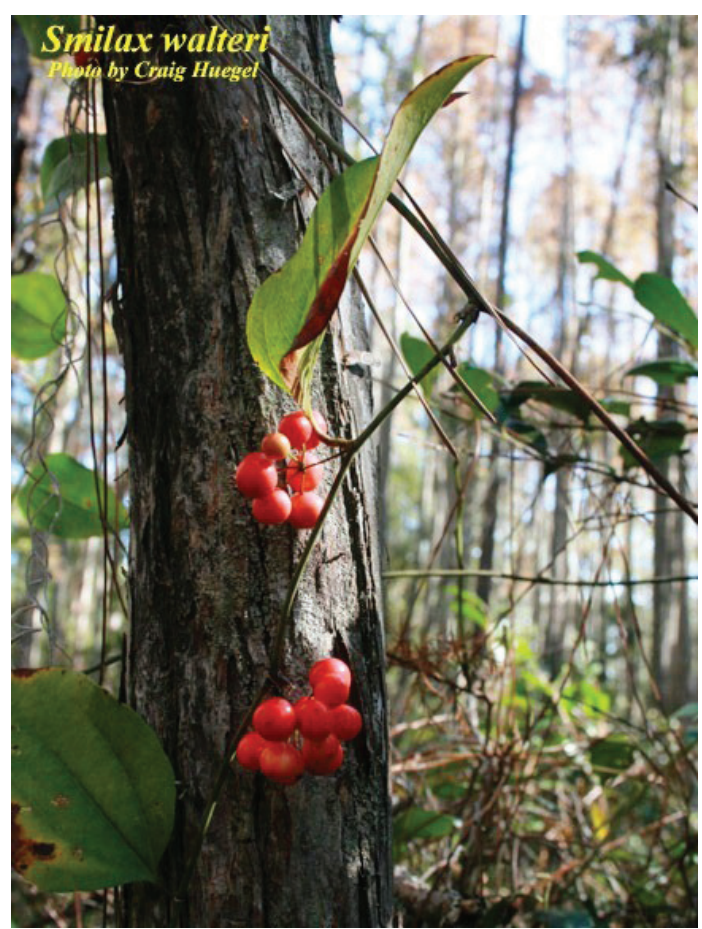

Figure 15. The bright red berries of Smilax walteri are persistent through winter.

Credits: Craig Huegel, Atlas of Florida Vascular Plants, plantatlas.usf. edu

Fruit: Winter. Persistent. Round berries, bright red when mature, up to $8 \mathrm{~mm}$ in diameter.

Distinguishing characteristics: Smilax walteri is deciduous, whereas all other Smilax species are evergreen. The bright red berries are persistent through the winter after the leaves have fallen. The berries are round, whereas the berries on $S$. pumila have a tapered apex.

\section{Recommended Reading}

Harris, J. G. and M. W. Harris. 2001. Plant Identification Terminology: An Illustrated Glossary, 2nd Edition. Spring Lake Publishing. Spring Lake, UT.

\section{References}

Duncan, W. H. 1975. Woody Vines of the Southeastern United States. Athens, Georgia: University of Georgia Press.

eFloras (2008). Missouri Botanical Garden, St. Louis, MO \& Harvard University Herbaria, Cambridge, MA. Accessed July 11, 2011 - August 22, 2011. Published on the Internet. Available: http://www.efloras.org

Florida Natural Areas Inventory (FNAI). 2010. Guide to the Natural Communities of Florida: 2010 Edition. Florida Natural Areas Inventory, Tallahassee, FL. 
Godfrey, R. K. 1988. Trees, Shrubs, and Woody Vines of Northern Florida and Adjacent Georgia and Alabama. Athens, Georgia: University of Georgia Press.

Hall, D. W. 1993. Illustrated Plants of Florida and the Coastal Plain. Maupin House, Gainesville, Florida.

Lance, R. 2004. Woody Plants of the Southeastern United States: A Winter Guide. Athens, Georgia: University of Georgia Press.

Nelson, G. 1996. The Shrubs and Woody Vines of Florida. Sarasota, Florida: Pineapple Press Inc.

USDA, NRCS. 2011. The PLANTS Database National Plant Data Team, Greensboro, NC 27401-4901 USA. Accessed July 11, 2011 - August 22, 2011. Available: http://plants. usda.gov

Wunderlin, R. P., and B. F. Hansen. 2008. Atlas of Florida Vascular Plants (http://www.plantatlas.usf.edu/). [S. M. Landry and K. N. Campbell (application development), Florida Center for Community Design and Research.] Institute for Systematic Botany, University of South Florida, Tampa. 